\title{
Sensitivity and evaluation of current fire risk and future projections due to climate change: the case study of Greece
}

\author{
A. Karali ${ }^{1}$, M. Hatzaki ${ }^{1}$, C. Giannakopoulos ${ }^{1}$, A. Roussos ${ }^{1}$, G. Xanthopoulos ${ }^{2}$, and V. Tenentes ${ }^{1}$ \\ ${ }^{1}$ Institute for Environmental Research and Sustainable Development, National Observatory of Athens, Athens, Greece \\ ${ }^{2}$ Institute of Mediterranean Forest Ecosystems and Forest Products Technology, Hellenic Agricultural Organization \\ "DEMETER", Athens, Greece
}

Correspondence to: A. Karali (akarali@noa.gr)

Received: 22 August 2013 - Published in Nat. Hazards Earth Syst. Sci. Discuss.: 12 September 2013

Revised: - - Accepted: 8 December 2013 - Published: 23 January 2014

\begin{abstract}
Current trends in the Mediterranean climate, and more specifically in Greece, indicate longer and more intense summer droughts that even extend out of season. In connection to this, the frequency of forest fire occurrence and intensity is on the rise. In the present study, the Canadian Fire Weather Index (FWI) is used in order to investigate the relationship between fire risk and meteorological conditions in Greece. FWI is a meteorologically based index designed in Canada and used worldwide, including the Mediterranean Basin, to estimate fire danger in a generalised fuel type based solely on weather observations. Here, an evaluation of the index is initially performed for the Greek territory using fire observations that cover a $15 \mathrm{yr}$ period. Three critical fire risk threshold values are established for the area of Greece based on daily mean meteorological data: $\mathrm{FWI}=15$, $\mathrm{FWI}=30$ and $\mathrm{FWI}=45$, increasing from the northwest to the southeast. Subsequently, a regional climate model is employed providing input for the FWI system to investigate the impacts of climate change on fire risk for two future time periods, 2021-2050 and 2071-2100, under the A1B emissions scenario. Days with critical fire risk are expected to increase by as many as 50 days per year by the end of the century.
\end{abstract}

\section{Introduction}

Forest fires constitute a major environmental and socioeconomic issue in the Mediterranean. An average of 50000 fires per year burn an area of 470000 ha annually, causing, in addition to ecological catastrophes, severe damages to infrastructures and, quite often, human casualties (Schmuck et al., 2011). Although forest fires were always present in the Mediterranean and the Mediterranean-climate-type forest areas are extremely fire-prone, their destructive capacity has been on the rise for the last few decades (Pausas and Vallejo, 1999) and an extension of the fire season has been reported (e.g. Flannigan et al., 2009; Dimitrakopoulos et al., 2011a).

A series of factors are thought to influence fire activity, such as weather conditions (Balling et al., 1992b), human activities (Vélez, 1993), fuel characteristics (e.g. Mouillot et al., 2002), fire management activities (Badia et al., 2002; Fried et al., 2008), topography and land use changes (Rego, 1992; Moreira et al., 2011), fire suppression policies and priorities, fire control organisational size and efficiency (Flannigan et al., 2005), and climate change (Davis and Michaelsen, 1995; Flannigan et al., 2000; Fried et al., 2004).

Greece, being part of the eastern Mediterranean Basin, is an area particularly vulnerable to climatic change regarding temperature rise and increased fire risk (Giannakopoulos et al., 2011). According to Founda et al. (2004), since the mid1970s most regions of Greece have experienced significant positive temperature trends that are more pronounced in summer; furthermore, starting in this period of time, Greece has entered a prolonged period of drought (e.g. Dalezios et al., 2000; Pnevmatikos and Katsoulis, 2006; Livada and Assimakopoulos, 2007) that has led to a significantly high number of fires and area burnt (Dimitrakopoulos et al., 2011a).

Simulations of regional climate models for the Greek territory suggest a further increase of summer air temperature accompanied by an extended dry period in the future (Giannakopoulos et al., 2011). Forest fires are highly sensitive to climate change, because fire behaviour responds 
immediately to fuel moisture (Weber and Flannigan, 1997; Stocks et al., 2001). Thus, the projected increase in temperature will lead to reduced relative humidity and increased fuel dryness. This effect will worsen in regions with lower rainfall (Howden et al., 2001). Accordingly, the rise in extreme weather events is expected to have a great impact on forest fire vulnerability (Beniston, 2003).

Although it has not yet been clarified as to whether the meteorological conditions or the landscape pattern fundamentally determine fire risk and spread (Moreira et al., 2011), it seems that the climatic and weather conditions in the Mediterranean have a profound effect on fire occurrence (Koutsias et al., 2013). Therefore, understanding the links between weather, climate and fires is important for implementing effective fire prevention policies; moreover, in a context of climate change, this is further needed in order to implement adaptation strategies. The contribution of meteorological factors to fire risk is assessed by various non-dimensional indices of fire risk.

There is a variety of fire danger rating systems used worldwide, including the Canadian Forest Fire Weather Index System (CFFWIS) used in Canada (Van Wagner, 1987), the National Fire Danger Rating System (NFDRS) used in the USA (Deeming et al., 1977) and the McArthur Forest Fire Danger Index (FFDI) used in Australian forests (Mc Arthur, 1967). In Europe, some well-known indices include the Finnish Fire Index (FFI), developed by the Finnish Meteorological Institute (Venäläinen and Heikinheimo, 2003); the Portuguese index (ICONA, 1988); and the Italian index (IREPI) proposed by Bovio et al. (1984). Viegas et al. (1999) validated several such indices in the Mediterranean against observed fire occurrence, with the Canadian Fire Weather Index (FWI) being among the best performers, while Viegas et al. (2004) presented a methodology for calibrating the fire danger classes based on daily FWI values, number of fires and area burnt.

The FWI model is non-dimensional, based on physical processes and has been used at several locations, including the Mediterranean Basin (Viegas et al., 2004; Moriondo et al., 2006, Carvalho et al., 2008; Dimitrakopoulos et al., 2011b; Giannakopoulos et al., 2012); indeed, since 2007 the FWI has been adopted at the EU level by the European Forest Fire Information System (EFFIS) of the Joint Research Centre of the European Commission (http://forest.jrc.ec.europa. eu/effis). This was done following a test phase of $5 \mathrm{yr}$, during which different fire danger methods were implemented in parallel by the EFFIS, until the FWI was selected as the method to assess the fire danger level in a harmonised way throughout Europe. Thus, it seems a sensible basis for exploring the mechanisms of fire risk and fire risk changes in Greece.

The present study aims to examine whether FWI values can adequately reflect fire risk for the Greek territory. Fire risk, i.e. the chance that a fire might start (Hardy, 2005), is associated here with the actual fire occurrence. Subsequently, the study aims to establish a relationship between FWI and fire risk and, as a next step, to estimate the projected changes in fire risk driven by climate change.

\section{Data and methodology}

\subsection{Study area}

Greece is located in the most southeastern part of Europe, in latitude from $35^{\circ} 00^{\prime} \mathrm{N}$ to $42^{\circ} 00^{\prime} \mathrm{N}$ and in longitude from $19^{\circ} 00^{\prime} \mathrm{E}$ to $28^{\circ} 30^{\prime} \mathrm{E}$, and is mainly bordered by sea. Greece belongs to the Mediterranean climatic type, which is characterised by mild winters with maximum precipitation, relatively warm and dry summers and a long sunshine duration almost throughout the year. The climate of Greece varies from continental Mediterranean in the north to subtropical Mediterranean in the south, with a rapidly decreasing continentality from north to south and from the interior to the coastal regions and islands. The wide variety of Mediterranean climate subtypes encountered in several regions is due to the influence of topography on the air coming from the moisture sources of the central Mediterranean Sea (HMSO, 1962). As a consequence, the western part of the Greek territory is generally wetter, while the eastern part is much drier and windier, mainly during the summer season. Moreover, the annual cycle can be divided climatologically into a cold and rainy period (October-March) as well as a warm and dry period (April-September), while October and April can be characterised as transition months (Zambakas, 1981).

\subsection{Station and model meteorological data}

The meteorological data for 13 stations covering the period 1983-1997 were obtained from the Hellenic National Meteorological Service (Fig. 1). Specifically, mean daily values of air maximum temperature, relative humidity, wind speed and $24 \mathrm{~h}$ accumulated precipitation were used in order to calculate daily values of FWI.

Present and future model output from the RACMO2 regional climate model (RCM) was also used. This model was developed within the framework of the EU project ENSEMBLES (www.ensembles-eu.org), in which the National Observatory of Athens participated. RACMO2 was provided by the Royal Netherlands Meteorological Institute, widely known as KNMI. The KNMI-RACMO2 regional climate model (Lenderink et al., 2003; van den Hurk et al., 2006) is forced with output from a transient run conducted with the ECHAM5 Global Climate Model. The RCM model uses 40 vertical levels on a horizontal $95 \times 85$ (lat. $\times$ long.) grid and has a horizontal resolution of $25 \mathrm{~km}$. The selection of this specific model was based on an assessment performed within the ENSEMBLES project. The ability of all the models to simulate the present climate was assessed, and KNMI-RACMO2 was found to more accurately simulate climate and extremes for the Mediterranean region (ENSEMBLES Deliverable D3.2.2). Daily mean values of the 


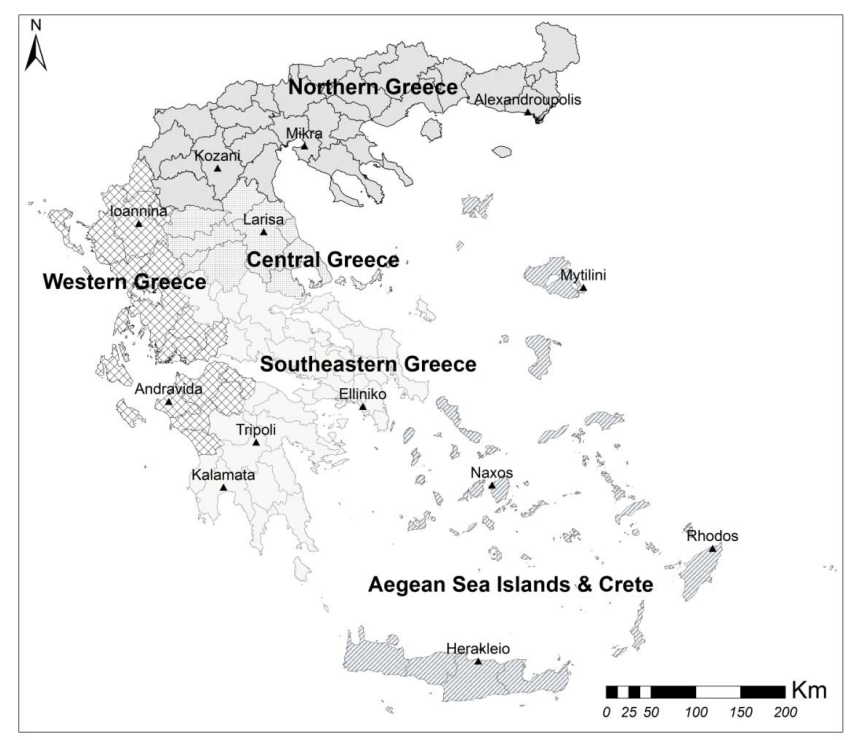

Fig. 1. Division of Greece into five sub-regions for the presentation of the fire base data and locations of the meteorological stations used.

aforementioned parameters were used, since only these values were readily available by the ENSEMBLES models. However, Herrera et al. (2013) warn that the use of daily mean data for the calculation of FWI may produce a slight to moderate loss of extreme event detection and should be used with caution.

In the present study, the control run represents the base period 1961-1990 and is used as a reference for comparison with future projections for the periods 2021-2050 (near future) and 2071-2100 (distant future). The future period simulations of the models are based on the IPCC SRES A1B scenario (Nakicenovic et al., 2000), which provides a good midline estimate for carbon dioxide emissions and economic growth (Alcamo et al., 2007).

\subsection{Forest fire data}

The data of fire events were provided by the Special Secretariat for Forests, Ministry of Environment, Energy \& Climate Change of Greece. Some 23150 fire events throughout Greece are registered in the study database, covering the period 1983-1997. During this period the responsibility for forest fire management belonged to the forest service, which also developed and maintained the forest fires database. Initially, the data were in the form of manually filled-in forms for each fire event by the local forest service office responsible for that area. The report contained a fully detailed description of the time (date and time) and site of the fire event (topography, geology and prevailing meteorological conditions at the time of the event), as well as details concerning the burnt areas (cultivation or forest type) and the suppression forces used. In this study, however, only the number of fire events and the total burnt area (agricultural and forest) were used.

The large number of forest fires that occur in the western part of Greece result in a relatively low burnt area, in comparison to the much larger burnt area that is caused by the much smaller (nearly half) number of fire events in eastern Greece, the Aegean Sea islands and Crete (Xanthopoulos and Varela, 1999). According to this differentiation, and in order to conduct a statistical analysis of the fire database, the entire Greek territory was initially divided into five different sub-regions following geographical criteria (Fig. 1).

The significant interannual variability of the number of fire events and the magnitude of destruction can mainly be attributed to the meteorological conditions of each year. Furthermore, a relation between successful firefighting and worse fires in subsequent years due to the resulting fuel accumulation is also hypothesised, at least for certain ecosystems (Venn and Calkin, 2011). From Fig. 2, it is evident that the year of 1993 had the highest number of fire events throughout Greece, while in 1997 the highest number of fire events occurred in western Greece alone and the same holds true for the area burnt due to these fire events. The years 1985 and 1988 were highly catastrophic, as all of the regions had large burnt areas. The year 1992 was also catastrophic, but only in the southeastern part of Greece.

The number of fire events is not directly associated with the burnt area, because they depend highly on parameters such as the meteorological conditions at the time of the event, the existing vegetation and topography of the site, the suppression operations and the number of simultaneous fire events, which obviously differ from year to year and from region to region.

The distribution of the fire events during the fire fighting season is also very important. As seen in Table 1, August is the month in which most of the fire events take place, except in northern Greece, the Aegean Sea islands and Crete. In these areas, most fires break out in September. The fires with agricultural origin play a role in this distribution: the number of forest fires originating from agricultural activities peaks in September for the whole country. In northern Greece, agricultural and livestock grazing activities are intense in early autumn, and causes such as wheat stubble burning are prominent in this time period. The two regions of northern Greece, Macedonia and Thrace, account for $70.2 \%$ of the total of forest fires of agricultural origin (Dimitrakopoulos and Mitsopoulos, 2005).

The temporal distribution of the burnt areas is highly variable among different months. August is the most catastrophic month in all regions except central Greece, where July is the month with the largest burnt areas. When compared to other months, burnt areas during August are almost double those burnt during July in northern and western Greece. It is also very interesting to note that the burnt areas in June are almost equal to those in October, a fact that is highly connected with the relative dryness of the vegetation affected by fire. 
Table 1. Monthly burnt area (BA) in hectares and number of fire events (NOF) for the five sub-regions of the Greek domain for the period 1983-1997.

\begin{tabular}{|c|c|c|c|c|c|c|c|c|c|c|c|c|}
\hline & \multicolumn{2}{|c|}{ May } & \multicolumn{2}{|c|}{ June } & \multicolumn{2}{|c|}{ July } & \multicolumn{2}{|c|}{ August } & \multicolumn{2}{|c|}{ September } & \multicolumn{2}{|c|}{ October } \\
\hline & BA & $\mathrm{NOF}$ & BA & NOF & $\mathrm{BA}$ & $\mathrm{NOF}$ & BA & $\mathrm{NOF}$ & $\mathrm{BA}$ & NOF & BA & NOF \\
\hline Western Greece & 1295 & 137 & 2825 & 357 & 45247 & 1261 & 69580 & 2357 & 26727 & 1616 & 6804 & 832 \\
\hline Central Greece & 202 & 34 & 5852 & 145 & 35289 & 361 & 29398 & 482 & 27738 & 470 & 8728 & 170 \\
\hline Southeastern Greece & 1001 & 293 & 22468 & 670 & 77627 & 1156 & 96154 & 1138 & 45053 & 866 & 16385 & 723 \\
\hline Northern Greece & 1318 & 133 & 5696 & 246 & 38190 & 721 & 74213 & 1060 & 31906 & 1150 & 8029 & 414 \\
\hline Aegean Sea Islands \& Crete & 1859 & 107 & 14591 & 362 & 49890 & 695 & 56698 & 703 & 30901 & 867 & 10613 & 615 \\
\hline
\end{tabular}
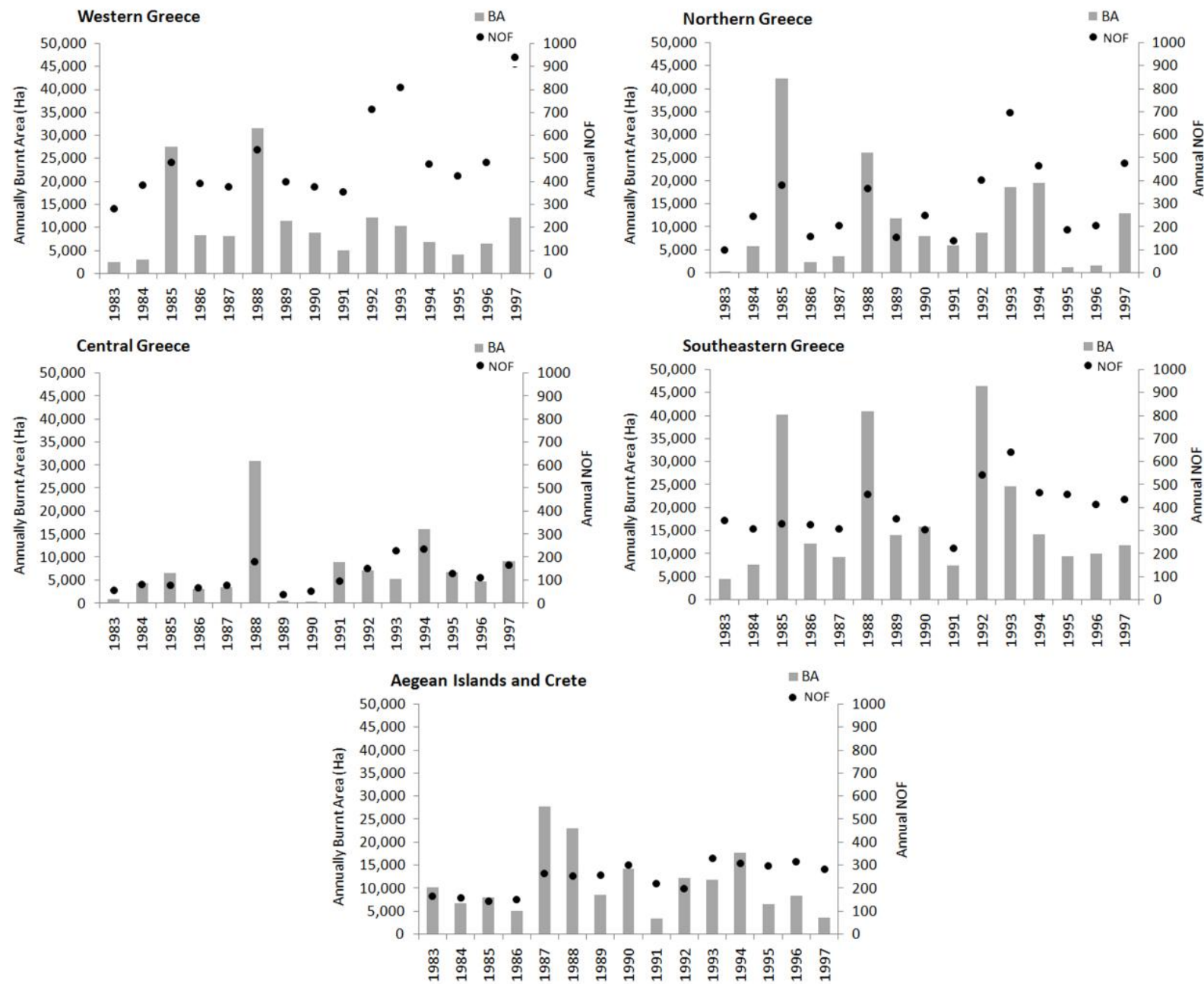

Fig. 2. Annually burnt area and number of fire events for the five sub-regions of the Greek domain for the period $1983-1997$.

\subsection{The Canadian Fire Weather Index - FWI}

\subsubsection{FWI structure}

As already mentioned, in order to assess forest fire risk, the Canadian Fire Weather Index (FWI) was used. FWI is a daily meteorologically based index used worldwide to estimate fire danger in a generalised fuel type. The FWI system provides numerical ratings of relative fire potential based solely on weather observations. The meteorological inputs to the FWI System are daily noon values of temperature, air relative humidity, $10 \mathrm{~m}$ wind speed and precipitation during the previous $24 \mathrm{~h}$, which are described in detail in van Wagner (1987). It should be noted that a spin-up for the initialisation of the index is necessary. Here, a spin-up period of $1 \mathrm{yr}$ has been applied. 
The FWI system consists of six standard components each measuring a different aspect of fire danger. The first three primary sub-indices are fuel moisture codes and are numerical ratings of the moisture content of litter and other fine fuels (FFMC), the average moisture content of loosely compacted organic layers of moderate depth (DMC) and the average moisture content of deep, compact organic layers (DC). Moisture code values for the current day are calculated from the day's observed weather and the previous day's fuel moisture code values. The two intermediate sub-indices (ISI, BUI) are fire behaviour indices. The Initial Spread Index (ISI) is a numerical rating of the expected fire rate of spread. It combines the effect of wind and FFMC on rate of spread without the influence of variable quantities of fuel. The Buildup Index (BUI) is a numerical rating of the total amount of fuel available for combustion that combines the DMC and the DC. The resulting index is the Fire Weather Index (FWI), which combines ISI and BUI. FWI represents the frontal fire intensity and is used to estimate the difficulty of fire control.

\subsubsection{FWI sensitivity test}

A sensitivity analysis of the index to the meteorological parameters was performed using the theoretical values for the calculation of FWI. In Fig. 3, families of curves of FWI as a function of the meteorological parameters used for its calculation are presented. It is found that the meteorological parameters with the highest impact on the index are precipitation and wind speed. Specifically, in Fig. 3a, it can be seen that even for moderate wind speed, the index exceeds the critical risk thresholds, as defined in the present study. For gale force winds, frequent in eastern Greece during summer, the index reaches extremely high values. This is also evident from Fig. 3b, where temperature increase has a higher impact on the index as wind speed takes higher values. In order to assess the impact of precipitation on the FWI, Fig. 3c and d are compared, where zero precipitation and $10 \mathrm{~mm}$ precipitation are assumed for the previous day, respectively. It can be seen that even a light rain can reduce the index values by $80 \%$, lowering them in general below the specified critical risk thresholds.

\section{Results and discussion}

\subsection{FWI validation}

For the evaluation of the FWI, the fire and the meteorological databases described in the previous section were used. The Greek territory was divided into 13 sub-regions, equal to the number of the available meteorological stations, covering about $10^{6}$ ha each, and each local forest service office was assigned to its adjacent meteorological station. Following this, the cumulative number of fires and area burnt that occurred in each day and in each sub-region were normalised at $10^{6}$ ha in order to obtain intercomparable results. Finally, the daily values of the FWI for the fire season were calculated. The index was then divided into unity bins and the average values of the number of fires and area burnt that occurred at each category were calculated for each sub-region, giving a relation between the FWI and the number of fires. The best estimated polynomial fit was applied to the data. Figure 4 presents the results for six sub-regions.

From the analysis of the results, based on the minimum FWI value that is needed in order to have one fire event in each normalised sub-region, a weather/fire occurrence pattern seems to emerge. This FWI value increases gradually from the northwest to the southeast, following in general the climatic regimes of the Greek territory, i.e. from high precipitation amounts (resulting in higher fuel moisture content) to substantially lower precipitation amounts and dry northern prevailing winds (mostly during the warm period of the year). From the spatial distribution of this FWI value, the examined stations can be roughly classified into three distinct areas of different fire behaviour (Table 2): western, northern, and eastern and southern Greece (hereafter referred to as WG, NG and EG/SG, respectively). Specifically, in WG one fire per day seems to occur when FWI $=15$ (Fig. 4a, b), while in NG the same is true when FWI $=30$ (Fig. 4c, d). For the EG/SG, which includes the eastern continental areas, the larger Aegean Sea islands and Crete, one fire per day occurs when FWI $=45$ (Fig. 4e, f). The results for the smaller islands of the Aegean do not seem to fit into a pattern as they show great variability in the relationship between fire events and FWI values, probably due to the small total number of fires and their particularly complex topography. These values can be considered as critical risk thresholds for fire occurrence in each area based on the set of combination of meteorological parameters used; that is, these thresholds are valid only if this particular set of daily mean values is used.

Our results signify that as we move further south and east, i.e. to hotter and drier conditions, higher values of FWI are needed to reach the threshold for appearance, on the average, of one actual fire per day. This can be explained by the well established knowledge that the wetter western side of Greece has a much higher density of fires than the southeastern part, which is drier and windier in the summer. For example, Xanthopoulos and Varela (1999) sorted the fire occurrence data of the 102 forest service offices in the country for the period 1983-1993. They noted that 8 out 10 offices with the highest number of fire events were in the western area of Greece. However, from the sorting by burnt area, it was found that no office from western Greece was included in the 10 offices with the highest burnt area. As fires in Greece are mostly of anthropogenic origin, it seems that in the western parts, people (mainly shepherds) tend to set fires for specific purposes as soon as the meteorological conditions permit some active spread. On the other hand, in the drier and windier conditions of southern and eastern Greece, where fires can easily get out of hand, fires are not started so easily by people. The 

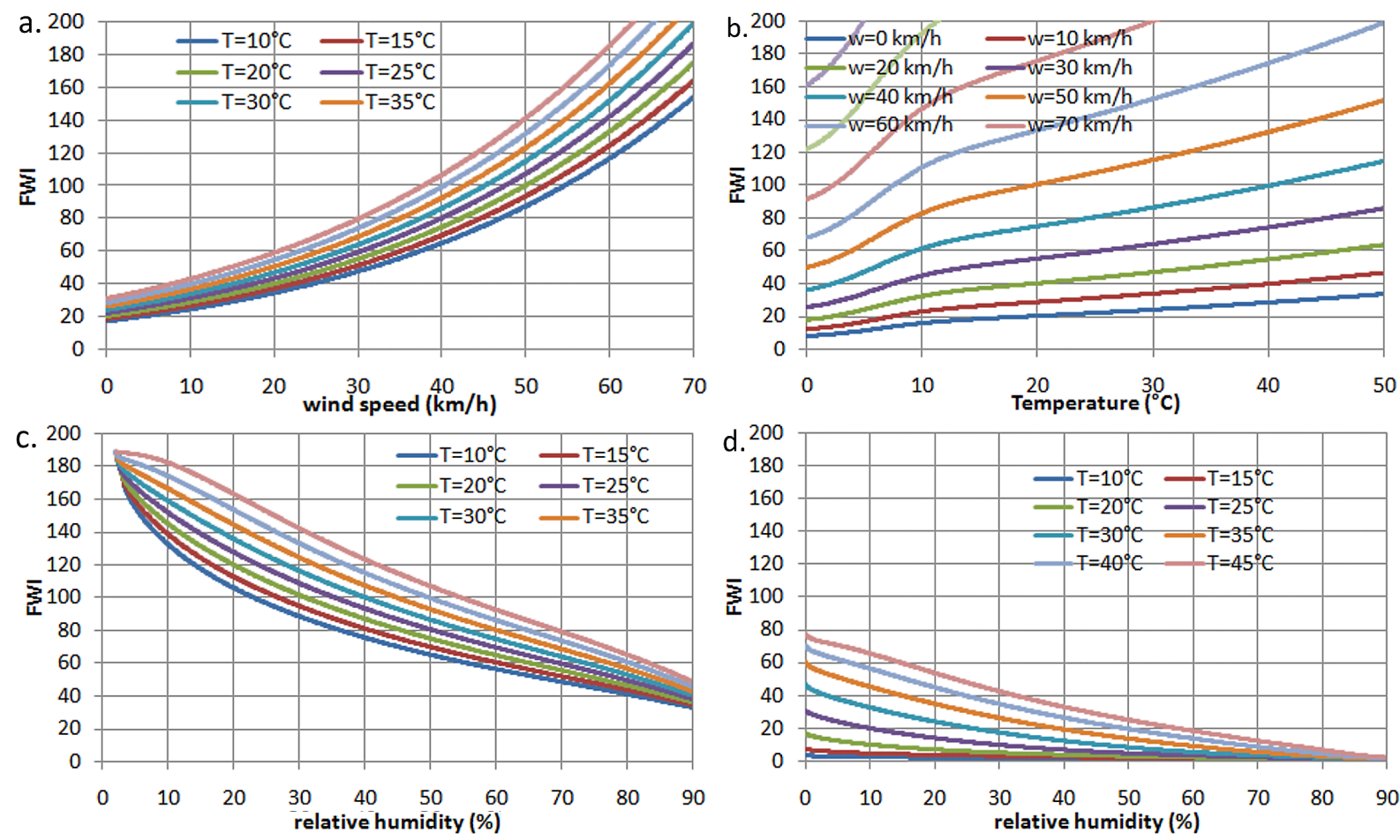

Fig. 3. Families of curves of FWI as a function of the meteorological parameters: (a) FWI as a function of wind speed (in $\mathrm{km} \mathrm{h}^{-1}$ ) for different temperatures and for $\mathrm{rh}=50 \%$ and zero precipitation, (b) FWI as a function of temperature (in ${ }^{\circ} \mathrm{C}$ ) for different values of wind speed and for $T=35^{\circ} \mathrm{C}$ and zero precipitation, (c) FWI as a function of relative humidity (\%) for different temperatures and for $w=40 \mathrm{~km} \mathrm{~h}^{-1}$ and zero precipitation, and (d) FWI as a function of relative humidity (\%) for different temperatures and for $w=40 \mathrm{~km} \mathrm{~h}^{-1}$ and $10 \mathrm{~mm}$ precipitation.

Table 2. Classification of the meteorological stations according to their fire risk behaviour.

\begin{tabular}{ll}
\hline Station & $\begin{array}{l}\text { Fire } \\
\text { behaviour } \\
\text { region }\end{array}$ \\
\hline Alexandroupoli & EG/SG \\
Andravida & WG \\
Elliniko & EG/SG \\
Herakleio & EG/SG \\
Ioannina & WG \\
Kalamata & EG/SG \\
Kozani & NG \\
Larisa & EG/SG \\
Mikra & NG \\
Mytilini & EG/SG \\
Naxos & - \\
Rhodos & - \\
Tripoli & EG/SG \\
\hline
\end{tabular}

probability of an inadvertently started fire due to human activities (e.g. works in the forest, discarded cigarettes, open barbecues) increases with increasing fire danger. Thus, the geographical differences in fuel load and in anthropogenic activities support the FWI threshold values resulting from the aforementioned analysis in the current study.

In regard to burnt areas, it should be noted that fire behaviour is subject to particularly complex factors, making the relation between weather conditions and burnt areas difficult to establish. In countries where anthropogenic influence on forest fires is small, such as in Canada, wildfire occurrence and burnt area are well correlated with FWI (Kiil et al. 1977; Stocks et al. 1989). In other cases, no conclusive evidence could be established that fire size increases with harsher weather conditions (e.g. Piñol et al., 1998; Good et al., 2008). However, other studies have shown that extreme fire weather could produce large fires whose spread is not determined by landscape structure (Salvador et al., 2005; Moritz et al., 2010). In this respect, the area burnt per fire event $(\mathrm{AB})$ in relation to the FWI was calculated for each sub-region (not shown). It was found that for WG, although the number of fires is relatively high, the $\mathrm{AB}$ is low even for the highest values of FWI, which is consistent with the findings of Xanthopoulos and Varela (1999). For EG/SG, some large fires (more than 100 ha according to Bermudez et al., 2009) occurred when the index took values greater than 50 . It is worth noting that for central Greece (see Fig. 1), which has extensive agricultural areas, the $\mathrm{AB}$ is high even for relatively small values of FWI (i.e. lower than the critical risk 

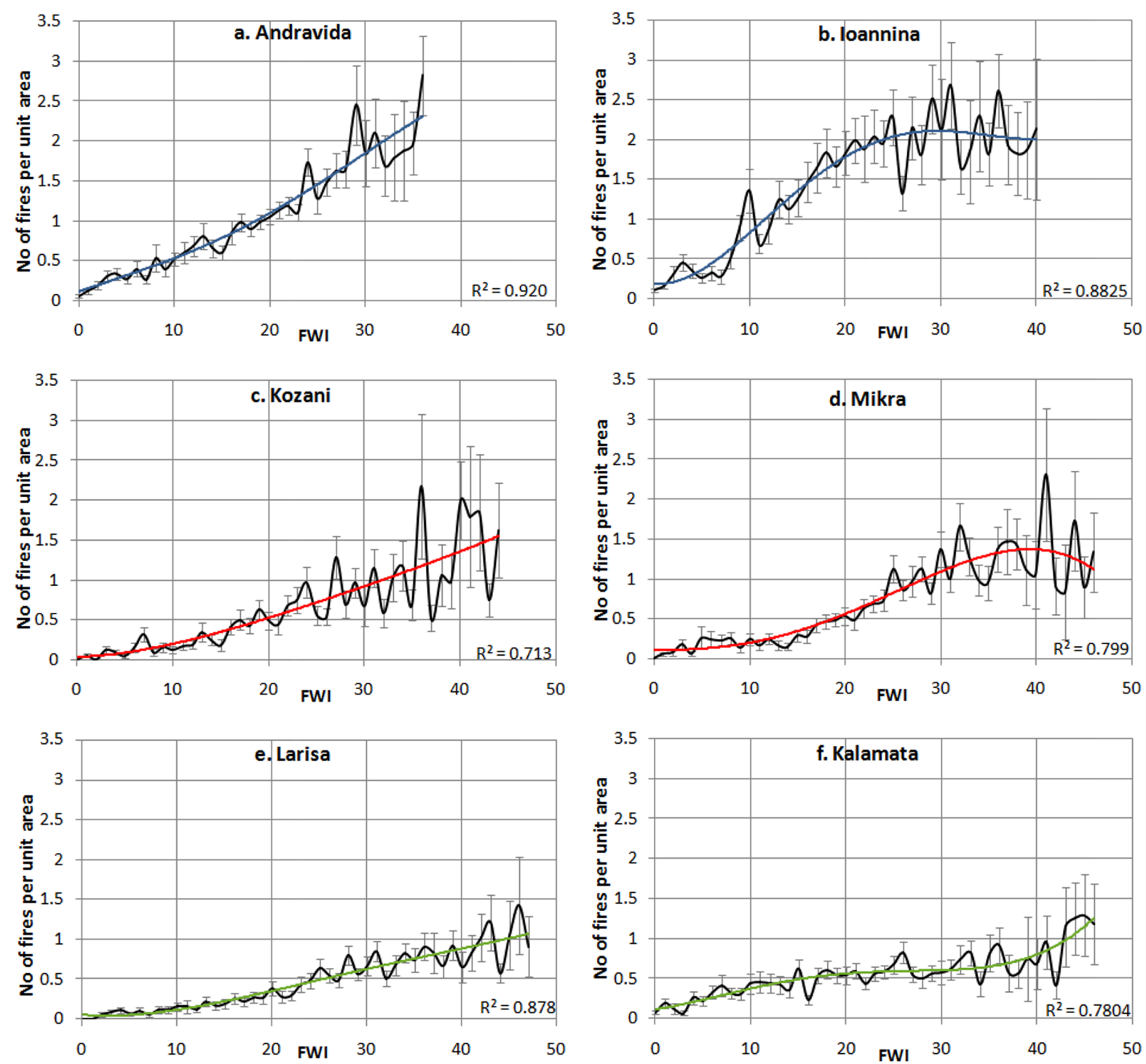

Fig. 4. Mean number of fires per unit area and per day against FWI and the respective polynomial fit for two indicative stations for each category of different FWI behaviour: (a) Andravida and (b) Ioannina in WG, (c) Kozani and (d) Mikra in NG, and (e) Larisa and (f) Kalamata in EG/SG for the 1983-1997 period. The error bars correspond to the standard error of each value.

threshold for the area). This can be attributed to intense agricultural activities (wheat stubble burning, burning by shepherds) which lead to the onset of fires that often expand to the neighbouring forests and shrublands.

\subsection{Future fire risk projections}

For the study region, the maps produced illustrate the mean number of days with FWI values above the critical fire risk threshold for each area of Greece - WG, NG and EG/SG - for the reference period (Fig. 5a-c), i.e. the period 19611990 , as well as the change in the number of days with critical fire risk (Fig. $5 \mathrm{~d}-\mathrm{i}$ ) between the reference and the two future periods (2021-2050 and 2071-2100).
As far as the reference period is concerned, the number of days with critical fire risk of western Greece (Fig. 5a) ranges between 70 days per year in the north of 130 days per year in the south. In northern Greece the number of days with critical fire risk reaches up to 90 per year (Fig. 5b). In eastern Greece the days with critical fire risk (Fig. 5c) for the current climate are low, except for the Attica region, eastern Peloponnese and Crete, where the days with critical fire risk vary between 20 and 50 days annually.

Calculating FWI based on climatic projections for the near future (2021-2050), an increase of up to 15 additional days of critical fire risk per year is expected in the western part of Greece (Fig. 5d). In northern Greece, an increase of 20 days per year is estimated (Fig. 5e). Eastern Greece demonstrates 


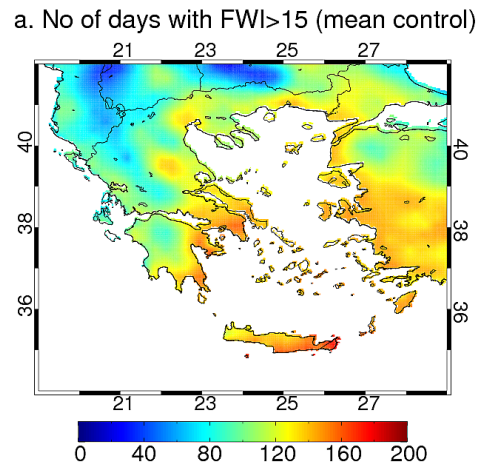

d. No of days with FWl>15 (near-control)

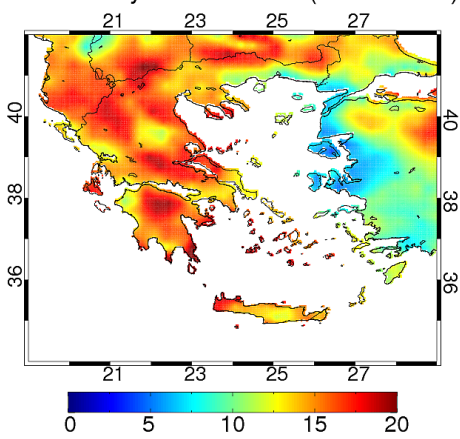

g. No of days with $\mathrm{FWl}>15$ (distant-control)

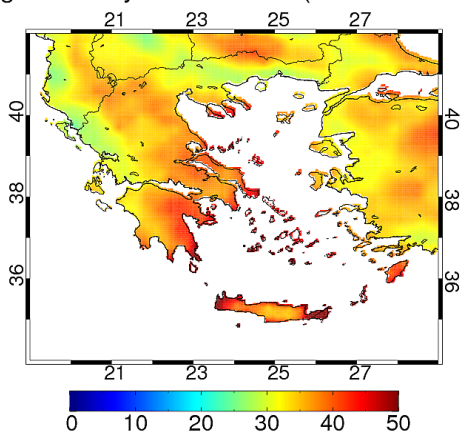

b. No of days with $\mathrm{FWI}>30$ (mean control)

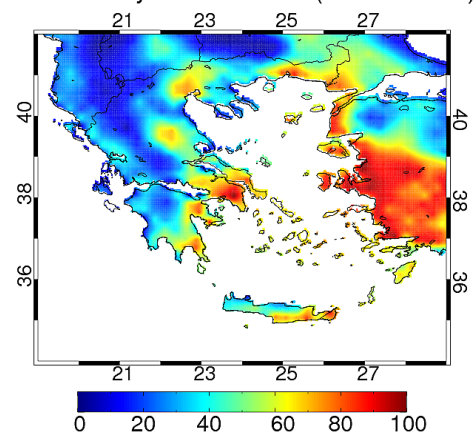

e. No of days with $\mathrm{FWl}>30$ (near-control)

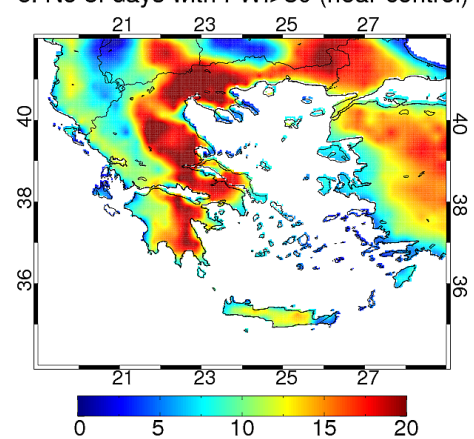

h. No of days with $\mathrm{FWl}>30$ (distant-control)

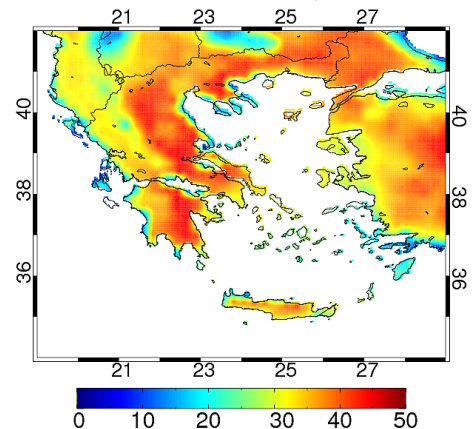

c. No of days with $\mathrm{FWl}>45$ (mean control)

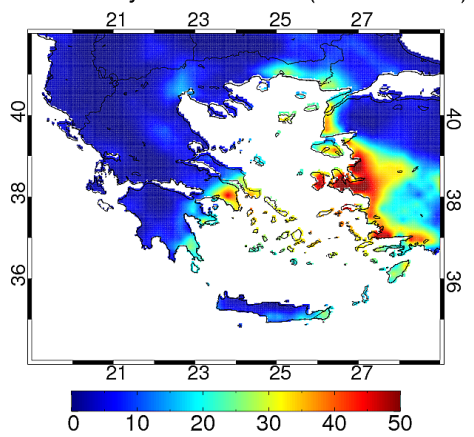

f. No of days with FWl>45 (near-control)

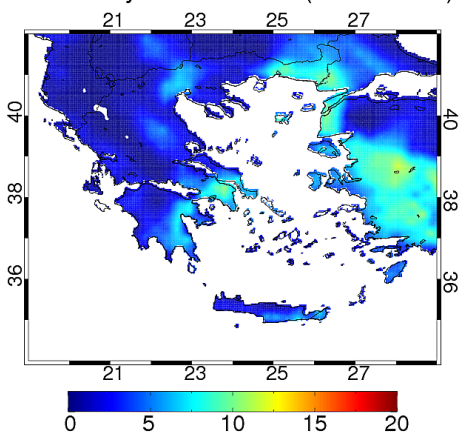

i. No of days with $\mathrm{FWl}>45$ (distant-control)

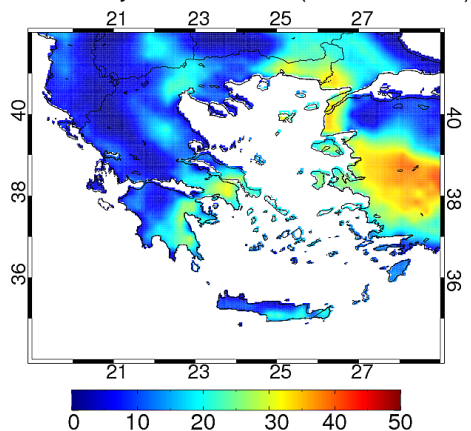

Fig. 5. (a, b, c) Mean number of critical fire risk days for the control period (1961-1990), (d, e, f) differences between the near future (20212050) and the control period, and (g, h, i) differences between the distant future (2071-2100) and the control period. Columns correspond to different subregions: (a, d, g) WG, (b, e, h) NG and (c, f, i) EG/SG.

lower values of 5 to 10 days (Fig. 5f). The most notable increases are estimated in the Attica Peninsula, eastern Peloponnese, central Macedonia, Thessaly and Crete (Fig. 5f).

By the end of the century, the increase for western Greece ranges between 25 and 40 days moving from north to south (Fig. 5g). In northern Greece the increase reaches 45 additional critical fire risk days per year (Fig. 5h). As far as eastern Greece is concerned, the model presents a rise of 20-30 days, while Attica, the Peloponnese and the northern Aegean islands hold the highest increases (Fig. 5i).

The reader should, however, be cautious when interpreting the changes depicted in the above maps, as Bedia et al. (2013) recommend against the use of threshold-dependent indices due to the high uncertainty associated with their future projections. It should, however, be noted that although the use of daily mean values of wind and relative humidity for FWI calculations may cause a bias compared to the use of noon values, this would be smaller than errors in assuming that noon observations at a fixed meteorological station are representative of conditions at the fire location, at arbitrary times of day, many kilometres from and at different altitudes to the measuring station. 


\section{Conclusions}

In this study, an evaluation of the FWI was performed using available current fire observations for Greece for a $15 \mathrm{yr}$ period and the index was confirmed to be capable of predicting fire occurrence. The critical threshold values of FWI for fire occurrence (one fire per day per area unit) vary spatially, increasing as we move from the northwest to the southeast of Greece. Three critical fire risk threshold values could be established: FWI $=15$ for western Greece, FWI $=30$ for northern Greece and FWI $=45$ for eastern and southern Greece (including eastern continental areas, the large Aegean Sea islands and Crete). These thresholds were not applicable for the small Aegean islands due to the complex local terrain and the small number of fire events.

Future fire risk projections suggested a general increase in fire risk over the domain of interest, with a very strong impact in the eastern Peloponnese, Attica, central Macedonia, Thessaly and Crete. In the near future, 15 to 20 additional critical fire risk days are expected in western and northern Greece. For eastern and southern Greece the increase reaches up to 10 days per year. For the distant future, the same pattern applies, with an increase of 30 to 40 days for western and northern Greece and 20 to 30 for eastern and southern Greece.

Acknowledgements. This work was supported by CLIM-RUN project (www.climrun.eu, grant agreement no. 265192), funded under the European Commission's Seventh Framework Programme (FP7). Regional climate model data were provided by the EU FP6 project ENSEMBLES (www.ensembles-eu.org).

Edited by: N. R. Dalezios

Reviewed by: P. Good and one anonymous referee

\section{References}

Alcamo, J., Moreno, J. M., Nováky, B., Bindi, M., Corobov, R., Devoy, R. J. N., Giannakopoulos, C., Martin, E., Olesen, J. E., and Shvidenko, A.: Europe, Climate Change 2007: Impacts, Adaptation and Vulnerability, Contribution of Working Group II to the Fourth Assessment Report of the Intergovernmental Panel on Climate Change, edited by: Parry, M. L., Canziani, O. F., Palutikof, J. P., van der Linden, P. J., and Hanson, C. E., Cambridge University Press, Cambridge, UK, 541-580, 2007.

Badia, A., Saurí, D., Cerdan, R., and Llurdés, J. C.: Causality and management of forest fires in Mediterranean environments: an example from Catalonia, Global Environ. Chang. B-Environ. Haz., 4, 23-32, 2002.

Balling, R. C., Meyer, G. A., and Wells, S. G.: Relation of surface climate and burned area in Yellostone National Park, Agr. Forest Meteorol., 60, 285-293, 1992.

Bedia, J., Herrera, S., Camia, A., Moreno, J. M., and Gutiérrez, J. M.: Forest fire danger projections in the Mediterranean using ENSEMBLES regional climate change scenarios, Clim. Chang., 122, 185-199, doi:10.1007/s10584-013-1005-z, 2013.
Beniston, M.: Climatic change in mountain regions: a review of possible impacts, Climatic Change 59, 5-31, 2003.

Bermudez, Z., Mendes, J., Pereira, J. M. C., Turkman, K. F., and Vasconcelos, M. J. P.: Spatial and temporal extremes of wild fire sizes in Portugal, Int. J. Wildland Fire, 18, 983-991, 2009.

Bovio, G., Quaglino, A., and Nosenzo, A.: Individuazione di un indice di previsione per il Peri-colo di Incendi Boschivi, Monti e Boschi Anno XXXV(4), 39-44, 1984.

Carvalho, A., Flannigan, M. D., Logan, K., Miranda, A. I., and Borrego, C.: Fire activity in Portugal and its relationship to weather and the Canadian Fire Weather Index System, Int. J. Wildland Fire, 17, 328-338, 2008.

Dalezios, R. N., Loukas, A., Vasiliadis, L., and Liakopoulos, E.: Severity-Duration-Frequency Analysis of Droughts and Wet Periods in Greece, Hydrol. Sci. J., 45, 751-768, 2000.

Davis, W. F. and Michaelsen, J.: Sensitivity of fire regime in chaparral ecosystems to climate change, in: edited by: Moreno, M. J. and Oechel, C. W., Global change and Mediterranean-type ecosystems, Ecological Studies, 117, Spinger, New York, 435456, 1995.

Deeming, J. E., Burgan, R. E., and Cohen, J. D.: The National Fire-Danger Rating System-1978, USDA Forest Service General technical Report INT-39, Intermountain Forest and Range Experiment Station, Ogden, UT, 1977.

Dimitrakopoulos, A. P. and Mitsopoulos, I. D.: Spatial and temporal distribution of forest fires originated from agricultural activities in Greece, 165-174, in: Proceedings of the 12th Panhellenic Forestry Conference on "Forest and Water" of the Panhellenic Forestry Association, October 2-5, 2005, Drama, Greece, Hellenic Forestry Society, Thessaloniki, Greece, vol. 1, 2005.

Dimitrakopoulos, A. P., Vlahou, M., Anagnostopoulou, Ch., and Mitsopoulos, I. D.: Impact of drought on wildland fires in Greece: implications of climatic change?, Clim. Chang., 109, 331-447, 2011a.

Dimitrakopoulos, A. P., Bemmerzouk, A. M., and Mitsopoulos, I. D.: Evaluation of the Canadian fire weather index system in an eastern Mediterranean environment, Met. Apps, 18, 83-93, doi:10.1002/met.214, 2011b.

ENSEMBLES Deliverable D3.2.2: RCM-specific weights based on their ability to simulate the present climate, calibrated for the ERA40-based simulations (www.ensembleseu.org).

Flannigan, M. D., Stocks, J. B., and Wotton, M. B.: Climate change and forest fires, Sci. Total Environ., 262, 221-229, 2000.

Flannigan, M. D., Logan, K. A., Amiro, B. D., Skinner, W. R., and Stocks B. J.: Future area burned in Canada, Clim. Chang., 72, $1-16,2005$.

Flannigan, M. D., Krawchuk, M. A., De Groot, W. J., Wotton, B. M., and Gowman, L. M.: Implications of changing climate for global wildland fire, Int. J. Wildland Fire, 18, 483-507, 2009.

Founda, D., Papadopoulos, K., Petrakis, M., Giannakopoulos, C., and Good, P.: Analysis of mean, maximum and minimum temperature in Athens from 1897-2001 with emphasis on the last decade: trends, warm events, and cold events, Global Planet. Change, 44, 27-38, 2004.

Fried, S. J., Torn, S. M., and Mills, E.: The impact of climate change on wildfire severity: a regional forecast for Northern California, Clim. Chang., 64, 169-191, 2004.

Fried, S. J., Gilless, J. K., Riley, W. J., Moody, T. J., de Bias, C. S., Hayhoe, K., Moritz, M., Stephens, S., and Torn, M.: Predict- 
ing the effect of climate change on wildfire behaviour and initial attack success, Clim. Chang., 87, 251-264, 2008.

Giannakopoulos, C., Kostopoulou, E., Varotsos, K., Tziotziou, K., and Plitharas, A.: An integrated assessment of climate change impacts for Greece in the near future, Reg. Environ. Change, 11, 829-843, 2011.

Giannakopoulos, C., LeSager, P., Moriondo, M., Bindi, M., Karali, A., Hatzaki, M., and Kostopoulou, E.: Comparison of fire danger indices in the Mediterranean for present day conditions, iForest, 5, 197-203, 2012.

Good, P., Moriondo, M., Giannakopoulos, C., and Bindi, M.: The meteorological conditions associated with extreme fire risk in Italy and Greece: relevance to climate model studies, Int. J. Wildland Fire , 17, 155-165, 2008.

Hardy, C.: Wildland fire hazard and risk: problems, definitions, and context. For. Ecol. Manag., 211, 73-82, 2005.

Herrera, S., Bedia, J., Gutierrez, J. M., Fernandez, J., and Moreno, J. M.: On the projection of future fire danger conditions with various instantaneous/mean-daily data sources, Clim. Chang., 118, 827-840, doi:10.1007/s10584-012-0667-2, 2013.

HMSO, Weather in the Mediterranean. I: General Meteorology, 2d ed. Her Majesty's Stationery Office, 362 pp., 1962.

Howden, S. M., Moore, J. L., McKeon, G. M., Reyenga, P. J., Carter, J. O., and Scanlan, J. C.: Global change and the mulga woodlands of southwest Queensland: greenhouse gas emissions, impacts, and adaptation, Environ. Int., 27, 161-166, 2001.

ICONA: Experimentacion de un nuevo sistema para determinacion del peligro de incendios forestales derivado de los combustibles: instrucciones de calculo, Instituto Nacional para la Conservacion de la Naturaleza, Madrid, Spain, 1988.

Kiil, A. D., Miyagawa, R. S., and Quintilio, D.: Calibration and performance of the Canadian Fire Weather lndex in Alberta, Environ. Can., Can. For Serv., North For. Res. Cent., Edmonton, Alta. Inf. Rep. NOR-X-173, 45 pp., 1977.

Koutsias, N., Xanthopoulos, G., Founda, D., Xystrakis, F., Nioti, F., Pleniou, M., Mallinis, G., and Arianoutsou, M.: On the relationships between forest fires and weather conditions in Greece from long-term national observations (1894-2010), Int. J. Wildland Fire, 22, 493-507, 2013.

Lenderink, G., van den Hurk, B., van Meijgaard, E., van Ulden, A. P., and Cuijpers, J. H.: Simulation of present-day climate in RACMO2: first results and model developments, KNMI Technical Report 252, 24 pp., 2003.

Livada, I. and Assimakopoulos, V. D.: Spatial and temporal analysis of drought in Greece using the Standardized Precipitation Index (SPI), Theor. Appl. Climatol., 89, 143-153, 2007.

Mc Arthur, A. G.: Fire Behaviour in Eucalypt Forests, Department of National Development, Forestry and Timber Bureau Leaflet No. 107, Canberra, Australia, 1967.

Moreira, F., Viedma, O., Arianoutsou, M., Curt, T., Koutsias, N., Rigolot, E., Barbati, A., Corona, P., Vaz, P., Xanthopoulos, G., Mouillot, F., and Bilgili, E.: Landscape-wildfire interactions in Southern Europe: implications for landscape management, J. Environ. Manag., 92, 2389-2402, 2011.

Moriondo, M., Good, P., Durao, R., Bindi, M., Giannakopoulos, C., Corte-Real, J.: Potential impact of climate change on fire risk in the Mediterranean area, Climate Res., 31, 85-95, 2006.

Moritz, M. A., Moody, T. J., Krawchuk, M. A., Hughes, M., and Hall, A.: Spatial variation in extreme winds predicts large wild- fire locations in chaparral ecosystems, Geophys. Res. Lett., 37, L04801, doi:10.1029/2009GL041735, 2010.

Mouillot, F., Rambal, S., and Joffre, R. Q: Simulating climate change impacts on fire frequency and vegetation dynamics in a Mediterranean-type ecosystem, Glob. Chang. Biol., 8, 423-437, 2002.

Nakicenovic, N., Alcamo, J., Davis, D., de Vries, B., Fenhann, J., Gaffin, S., Gregory, K., Grübler, A., Tae Yong Jung, Kram, T., La Rovere, E., Michaelis, L., Mori, S., Morita, T., Pepper, W., Pitcher, H., Price, L., Riahi, K., Roehrl, A., Rogner, H., Sankovski, A., Schlesinger, M., Shukla, P., Smith, S., Swart, R., van Rooijen, S., Victor, N., and Dadi, Z.: Special Report on Emission Scenarios, Working Group III of the Intergovernmental Panel on Climate Change (IPCC), Cambridge University Press, Cambridge, 595 pp., 2000.

Pausas, J. G. and Vallejo, R.: The role of fire in European Mediterranean ecosystems, in: Remote sensing of large wildfires in the European Mediterranean basin, edited by: Chuvieco, E., Springer-Verlag, Berlin, 3-16, 1999.

Piñol, J., Terradas, J., and Lloret, F.: Climate warming and wildfire hazard and wildfire occurrence in coastal eastern Spain, Clim. Chang., 38, 345-357, 1998.

Pnevmatikos, J. D. and Katsoulis, B. D.: The changing rainfall regime in Greece and its impact on climatological means, Meteorol. Appl., 13, 331-345, 2006.

Rego, F. C.: Land use changes and wildfires, in: Response of forest fires to environmental change, edited by: Teller, A., Mathy, P., and Jeffers, J. N., Elsevier, London, 367-373, 1992.

Salvador, R., Lloret, F., Pons, X., and Piñol, J.: Does fire occurrence modify the probability of being burned again? A null hypothesis test from Mediterranean ecosystems in NE Spain, Ecol. Model., 188, 461-469, 2005.

Schmuck, G., Ayanz, J. S. M., Camia, A., Durrant, T., Oliveira, S. S., Boca, R., Whitmore, C., Giovando, C., Libertà, G., Corti, P., and Schulte, E.: Report No 11, Forest Fires in Europe 2010. Joint Research Centre - Institute for Environment and Sustainability, Land Management and Natural Hazards Unit, Publications Office of the EU, Luxembourg, 8-11, 2011.

Stocks, B. J., Lynham, T. J., Lawson, B. D, Alexander, M. E., Van Wagner, C. E., McAlpine, R. S., and Dubé D. E.: Canadian Forest Fire Danger Rating System: An Overview, Forest, Chron., 65, 258-265, 1989.

Stocks, B. J., Wotton, B. M., Flannigan, M. D., Fosberg, M. A., Cahoon, D. R., and Goldammer, J. G.: Boreal forest fire regimes and climate change, in: Remote Sensing and Climate Modeling: Synergies and Limitations, Advances in Global Change Research, edited by: Beniston, M. and Verstraete, M. M., Kluwer Academic Publishers, Dordrecht and Boston, 2001.

van den Hurk, B. J. J. M., Klein Tank, A. M. G., Lenderink, G., van Ulden, A. P., van Oldenborgh, G. J., Katsman, C. A., van den Brink, H. W., Keller, F., Bessembinder, J. J. F., Burgers, G., Komen, G. J., Hazeleger, W., and Drijfhout, S. S.: KNMI Climate Change Scenarios 2006 for the Netherlands, KNMI-publication: WR-2006-01, 82 pp., 2006.

van Wagner, C. E.: Development and structure of a Canadian forest fire weather index system, Forestry Tech. Rep. 35, Canadian Forestry Service, Ottawa, 1987. 
Vélez, R.: High intensity forest fires in the Mediterranean Basin: natural and socioeconomic causes, Disaster Manag., 5, 16-20, 1993.

Venäläinen, A. and Heikinheimo, M.: The Finnish forest fire index calculation system, in: Early warning systems for natural disaster reduction, edited by: Zschau, J. and Kuppers, A., Springer, 645648, 2003.

Venn, T. J. And Calkin D. E.: Accommodating non-market values in evaluation of wildfire management in the United States: challenges and opportunities, Int. J. Wildland Fire, 20, 327-339, 2011.

Viegas, D. X., Bovio, G., Ferreira, A., Nosenzo, A., and Sol, B.: Comparative study of various methods of fire danger evaluation in southern Europe, Int. J. Wildland Fire, 9, 235-246, 1999.
Viegas, D. X., Reis, R. M., Cruz, M. G., and Viegas, M. T.: Calibração do sistema canadiano de perigo de incêndio para aplicação em Portugal, Silv. Lusit., 12, 77-93, 2004.

Weber, M. G. and Flannigan, M. D.: Canadian boreal forest ecosystem structure and function in a changing climate: impact on fire regimes, Environ. Rev., 5, 145-166, 1997.

Xanthopoulos, G. and Varela V.: Forest fire risk distribution in Greece based on the data for the 1983-93 period, Geotechnical Scientific Issues (Geotechnical Chamber of Greece), vol. 10 (issue II) - No 2, 178-190, 1999 (in Greek).

Zambakas, J. D.: General Climatology, Athens, 494 pp., 1981 (in Greek). 